\title{
Effect of 19-Norandrostenololylaurate on Testicular Growth in Colts
}

\author{
By E. Koskinen ${ }^{1}$, M. Andersson ${ }^{2}$, and T. Katila ${ }^{2}$ \\ ${ }^{1}$ Agricultural Research Centre, Equine Research, Ypäjä, and ${ }^{2}$ Animal Reproduction, Faculty of Veterinary \\ Medicine, University of Helsinki, Finland.
}

\begin{abstract}
Koskinen, E., M. Andersson, and T. Katila: Effect of 19-norandrostenololylaurate on testicular growth in colts. Acta vet. scand. 1997, 38, 51-57. - The effect of anabolic steroid on testicular growth was investigated in 3 experiments. In experiment I, $500 \mathrm{mg}$ of the anabolic steroid was given to 4 colts and $100 \mathrm{mg}$ to another 4 colts, every 3 rd week, starting at age 16 months and ending at age 24 months. Six colts served as controls. Both treatments decreased total scrotal width (TSW) within 6 weeks. Seasonal testicular growth during spring partly overcame the effect of steroid treatment. Cessation of anabolic steroid treatment was followed by testicular growth at the same time as TSW in untreated colts was decreasing by virtue of the effect of the season. Four months after the last injection, TSW was smaller in the treated animals than in the untreated animals, but the difference was not statistically significant.

In experiment II, steroid was given at a dose of $1 \mathrm{mg} / \mathrm{kg}$ every 3rd week to 4 colts and $0.3 \mathrm{mg} / \mathrm{kg}$ every week to 4 colts. Six colts served as controls. The animals were 7 months old at the start of treatment and 12 months old at the end of treatment. Treatments decreased testicular widths (TW), within 6-9 weeks. In this experiment, also, cessation of anabolic steroid treatment was followed by testicular growth. Twelve months after the last treatment, TW was smaller in treated than in untreated animals but the difference was not statistically significant.

In experiment III, foals were used which were 3 months old at the start and 8 months old at the end of treatment. The steroid was given at a dose of $1 \mathrm{mg} / \mathrm{kg}$ every $3 \mathrm{rd}$ week to 3 foals. Three foals served as controls. Treatment decreased TW within 6 weeks. Cessation of treatment was followed by a slow testicular growth. Growth similar to that in control animals started after a delay of 4-5 months. TW in treated animals nearly reached TW in controls within 12 months of cessation of treatment.
\end{abstract}

stallion; anabolic; steroids; season.

\section{Introduction}

Although use of anabolic steroids in horses is illegal in many countries, it is believed that they are used during training to improve performance, and in young foals to improve body condition for yearling sales. It has been shown that administration of anabolic steroids can decrease testicular size in stallions (Berndtson et al. 1979, Blanchard et al. 1983, Squires et al. 1982), and that such testicular changes can be reversible (Squires et al. 1981). However, effects on the prepubertal testis are unknown (Varner et al. 1991). There is no published information available on dosages of drugs, treatment intervals, treatment durations, or ages of animals at the beginning of treatment. Whether testicular growth is delayed or permanently altered by anabolic steroid treatment is unknown. Administration of anabolic steroids is often 
Table 1. Treatment of colts with 19-norandrostenololylaurate.

\begin{tabular}{lccccc}
\hline & $\begin{array}{c}\text { Number } \\
\text { of } \\
\text { animals }\end{array}$ & $\begin{array}{c}\text { Age at } \\
\text { start of } \\
\text { treatment } \\
\text { (months) }\end{array}$ & $\begin{array}{c}\text { Age at } \\
\text { end of } \\
\text { treatment } \\
\text { (months) }\end{array}$ & $\begin{array}{c}\text { Dose } \\
\text { level }\end{array}$ & $\begin{array}{c}\text { Dosage } \\
\text { inter- } \\
\text { val }\end{array}$ \\
\hline Experiment I & 6 & - & - & Untreated & - \\
Experiment II & 4 & 16 & 24 & $100 \mathrm{mg}$ & 3 weeks \\
& 4 & 16 & 24 & $500 \mathrm{mg}$ & 3 weeks \\
Experiment III & 6 & - & - & Untreated & - \\
& 4 & 7 & 12 & 1 mg/kg & 3 weeks \\
& 3 & - & - & $0.3 \mathrm{mg} / \mathrm{kg}$ & 1 week \\
\hline
\end{tabular}

said to be the cause of small testicles in stallions that have finished their racing careers and been retired for breeding (Woods et al. 1980). In the 3 experiments reported here, effects of administration of different doses of an anabolic steroid on testicular growth were investigated. Our aim was to investigate whether any age group of colts experienced irreversible changes with regard to testicular size after anabolic steroid treatment. The anabolic steroid preparation used was Laurabolin, a single injection of which according to the manufacturer has a high level of anabolic activity for 3 weeks.

\section{Materials and methods}

The animals used were Finnhorse colts raised for trotting and riding. Finnhorse is a coldblooded breed, the adult horse weighing 500 $600 \mathrm{~kg}$. The colts were not trained, but started on light exercise at 3 years of age. They were kept on pasture from June to September. During winter they were in an unheated barn with free access to a paddock. Three experiments were carried out: the first starting in autumn, the second at the start of the following year, and the third in autumn 2 years later. All colts in the 3 experiments were born in May or June except for 3 born in April, July and August. The anabolic steroid used was an injectable 19-norandrostenololylaurate preparation (Laurabolin vet $^{\circledR}$, Intervet International B.V., 5830 AA Boxmeer, The Netherlands). The manufacturer recommends a dose of 100-200 mg every 3 weeks for adult horses, e.g. to aid in recovery after a major operation. The recommended dose corresponds to a dose of $0.2-0.4 \mathrm{mg} / \mathrm{kg}$ for a $500 \mathrm{~kg}$ horse. Because people are said to use much higher doses of steroids for doping than the therapeutical dose, the higher dose chosen in experiment I was $500 \mathrm{mg}$ for colts which weighed roughly $400 \mathrm{~kg}$ during the treatment period. The dose in experiments II and III was calculated in $\mathrm{mg} / \mathrm{kg}$ of body weight. The treatment period varied between 5 and 8 months. The treatment protocols in experiments I-III are shown in Table 1.

In experiment I, the largest cross-sectional width of the testes was measured as total scrotal width, using the thumb and middle finger as calipers. In experiments II and III, widths of the left and right testicles were measured by means of a new ultrasound scanner1. Sums of echo-

\footnotetext{
${ }^{1}$ Aloka SSD-210 DX 5MHz, Japan.
} 


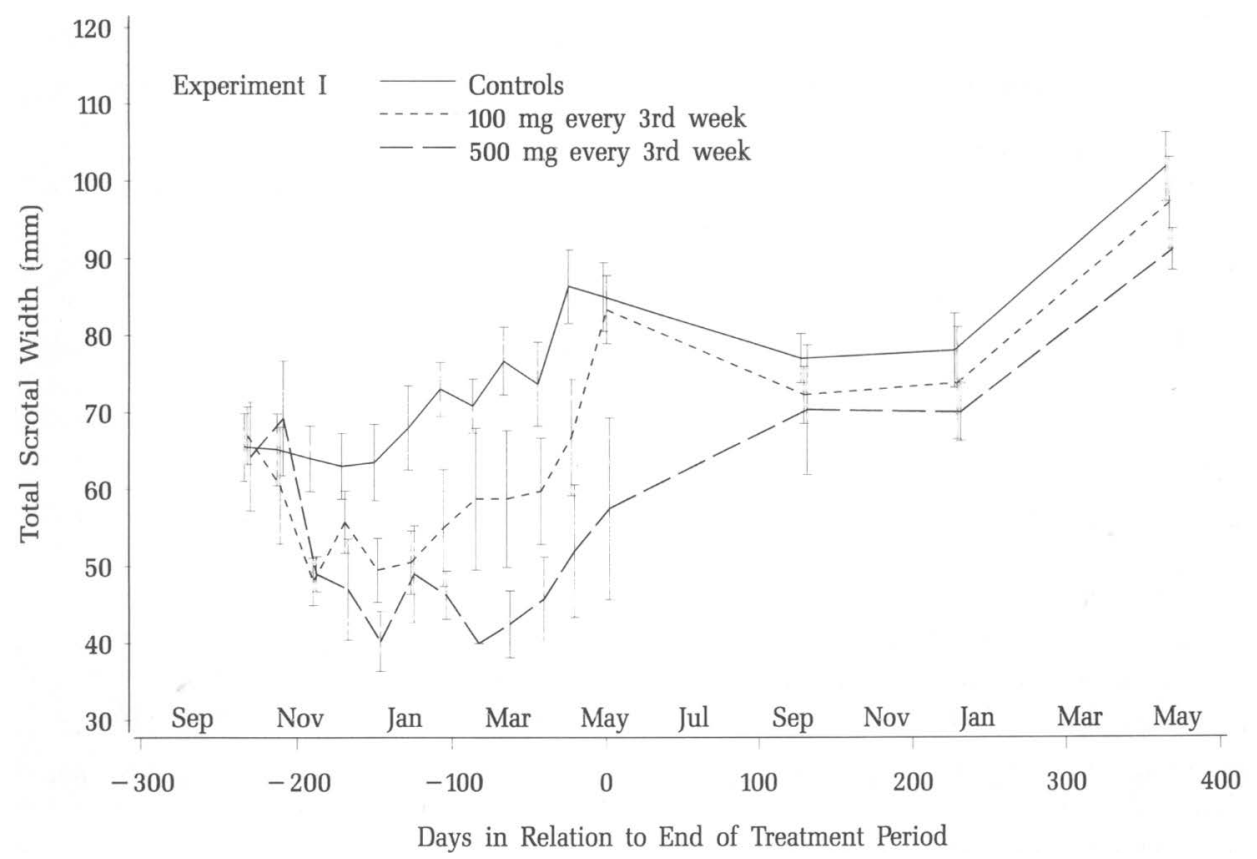

Figure 1. Mean \pm SEM of total scrotal width (TSW) in control colts and treated colts after treatment with 100 $\mathrm{mg}$ or $500 \mathrm{mg}$ of anabolic steroid every $3 \mathrm{rd}$ week between 16 and 24 months of age.

graphic measure ments were calculated. Testicular width correlates well with weight of testicular parenchyma (Thompson et al. 1979). Measurements were undertaken in all experiments every 3rd week from the beginning of treatment until the following May, when the colts went to pasture. Testicular width was subsequently measured 3 times a year, in autumn, winter, and May, until the difference in widths between groups in the same experiment was no longer statistically significant.

\section{Statistical analyses}

Analysis of variance, followed by Tukey's test when necessary, was used to test the significance of differences in testicular width between treatment groups.

\section{Results}

Experiment I

Initial total scrotal widths (TSW) did not differ between groups $(p=0.9403)$. Both the $100 \mathrm{mg}$ and $500 \mathrm{mg}$ treatments decreased TSW within 6 weeks. Testicles grew during spring in both treated groups, despite anabolic steroid treatment. During the treatment period, group mean TSW differed significantly between treatments $(\mathrm{p}=0.0198)$. The Tukey test $(\alpha=0.05)$ indicated that both the $500 \mathrm{mg}$ and the $100 \mathrm{mg}$ groups differed from the control group but 500 $\mathrm{mg}$ group and $100 \mathrm{mg}$ groups did not differ from each other. However, the $100 \mathrm{mg}$ group was less affected than the $500 \mathrm{mg}$ group. Four months after the last treatment, TSW was smaller in treated animals, than in control animals, but the difference was not significant $(p=0.4964$, Fig. 1). 


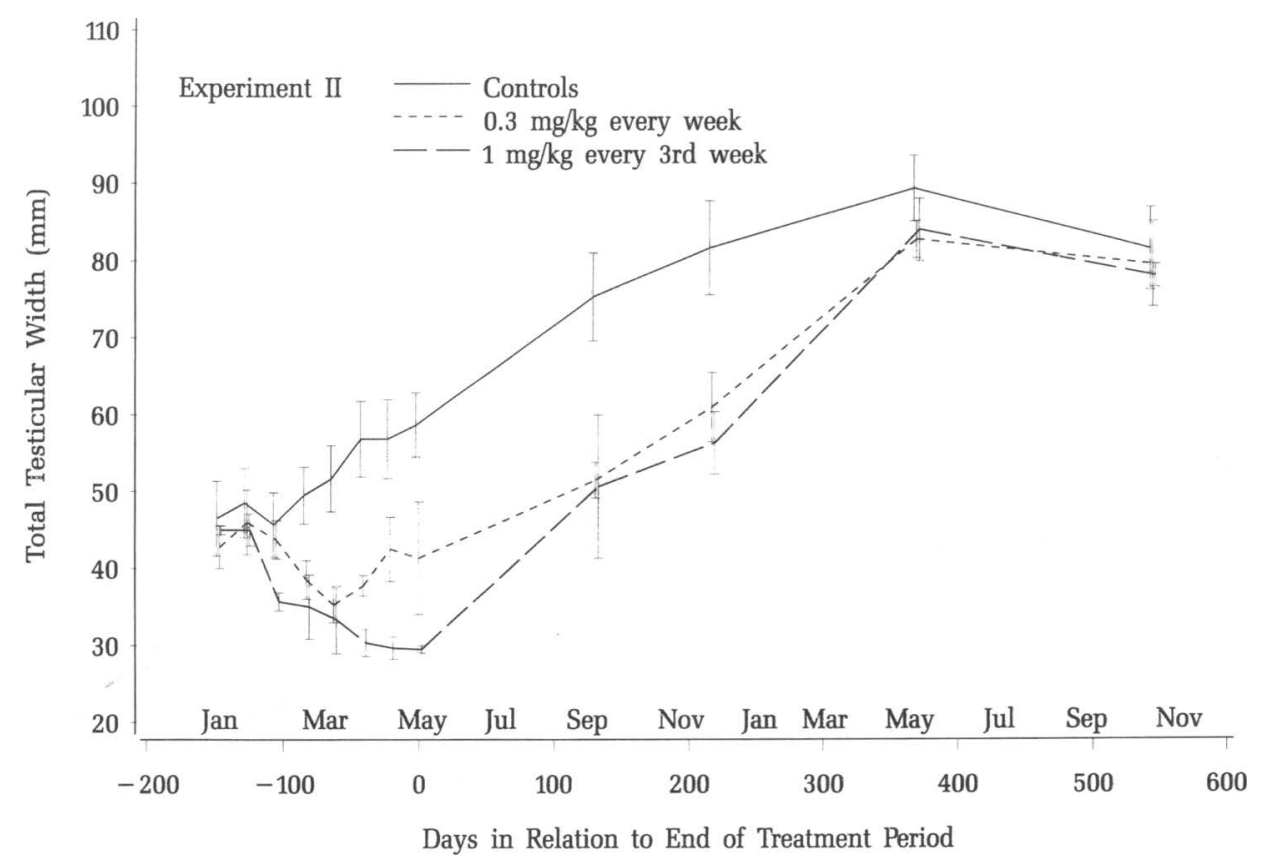

Figure 2. Mean $\pm \mathrm{SEM}$ of testicular width (TW) in control colts and treated colts after treatment with $1 \mathrm{mg} / \mathrm{kg}$ every $3 \mathrm{rd}$ week or $0.3 \mathrm{mg} / \mathrm{kg}$ every week of anabolic steroid between 7 and 12 months of age.

\section{Experiment II}

Testicular width was initially similar between groups $(\mathrm{p}=0.8146)$. Both $1 \mathrm{mg} / \mathrm{kg}$ every $3 \mathrm{rd}$ week and $0.3 \mathrm{mg} / \mathrm{kg}$ every week caused TW to decline, within 6-9 weeks. Despite anabolic steroid treatment, the testicles grew in the 0.3 $\mathrm{mg} / \mathrm{kg}$ every week group in spring. No growth occurred in the $1 \mathrm{mg} / \mathrm{kg}$ every 3rd week group. From the time of measurement of initial TW until one year after treatment, group means differed significantly between groups $(\mathrm{p}=0.0182)$. Results of the Tukey test $(\alpha=0.05)$ indicated that the $1 \mathrm{mg} / \mathrm{kg}$ every $3 \mathrm{rd}$ week group differed from the control groups, but the $0.3 \mathrm{mg} / \mathrm{kg}$ every week group did not. One year after the last anabolic steroid injection, TW was smaller in treated colts than in control colts. The difference was not, however, significant ( $p=0.4963$, Fig. 2).

\section{Experiment III}

Initial TW did not differ significantly between groups $(p=0.292)$. Steroid treatment diminished TW within 6 weeks. After treatment, testicles grew slowly in treated animals, and difference in TW between groups increased. In the following autumn, difference in TW decreased. Group mean TW from the start of treatment until one year after the final treatment differed significantly $(p=0.0016)$. One year after treatment, TW was smaller in treated animals. However, the difference was not statistically significant $(p=0.1234$, Fig. 3).

\section{Discussion}

In the experiments on the 3 age groups of young colts reported here, we observed significant inhibition of testicular growth and decrease of 


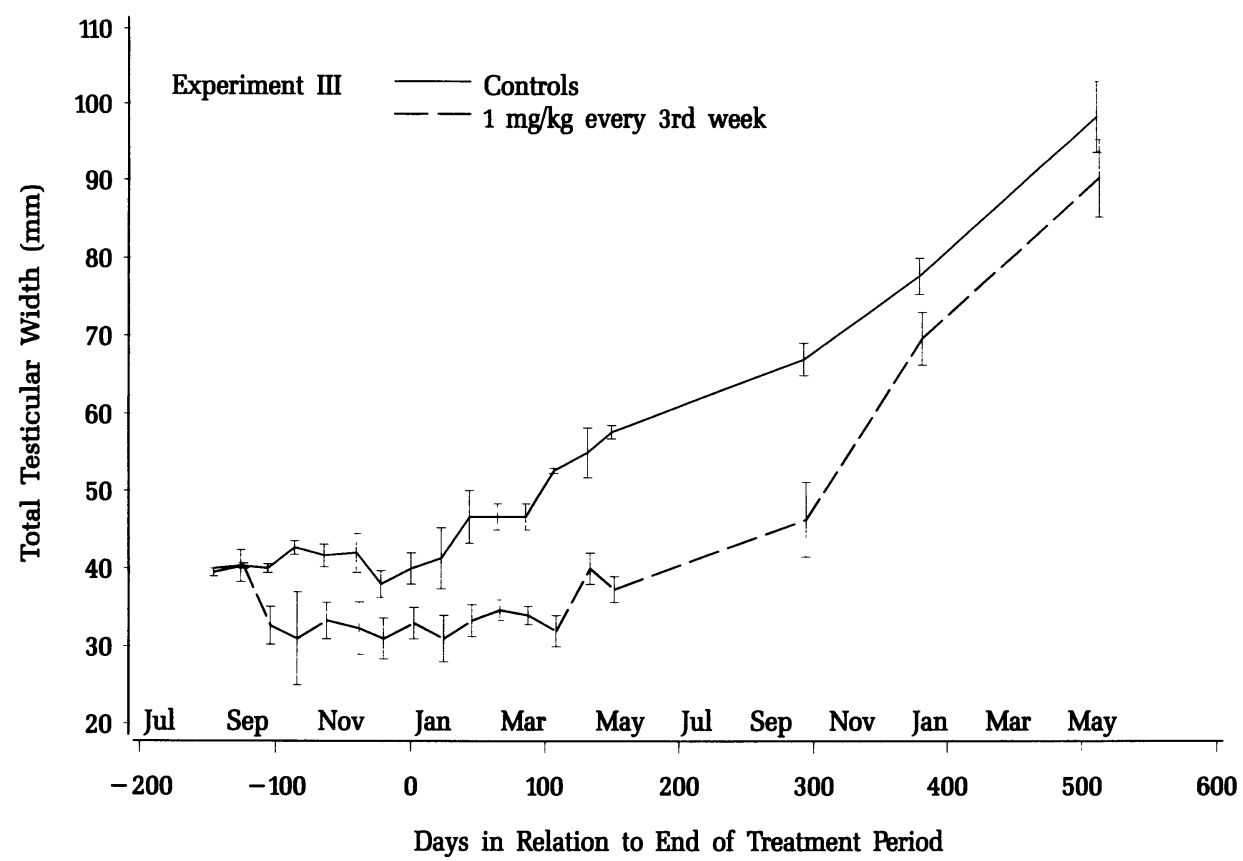

Figure 3. Mean \pm SEM of testicular width (TW) in control colts and treated colts after treatment with $1 \mathrm{mg} / \mathrm{kg}$ every 3 rd week of anabolic steroid between 3 and 8 months of age.

testicular size after treatment with doses of 500 $\mathrm{mg}$ of 19-norandrostenololylaurate every 3rd week or $1 \mathrm{mg} / \mathrm{kg}$ every $3 \mathrm{rd}$ week. There is no information on the effects of steroid treatment on young colts or foals in the literature. Our findings are comparable to findings in stallions. Treatment with nandrolone decanoate (1.1 $\mathrm{mg} / \mathrm{kg}$ every 3rd week), boldenone undecylenate (1.1 and $4.4 \mathrm{mg} / \mathrm{kg}$ every 3rd week) (Squires et al. 1982), boldenone undecylenate $(0.55 \mathrm{mg} / \mathrm{kg}$ every week) and stanozolol (1.1 $\mathrm{mg} / \mathrm{kg}$ every 3rd week) (Blanchard et al. 1983) has been shown to decrease scrotal width. It is only logical that in experiment I the low-dose group receiving $100 \mathrm{mg}$ every 3rd week was less affected than the high-dose group receiving $500 \mathrm{mg}$ every $3 \mathrm{rd}$ week. In experiment II, the reason for the weaker effect of the steroid in the high-dose group, when the dose was given by injections as $0.3 \mathrm{mg} / \mathrm{kg}$ weekly, is probably the differences in serum concentrations of the drug. We did not study serum concentrations of Laurabolin or its metabolites, but peak concentrations of the steroid after injections every $3 \mathrm{rd}$ week could influence the hormonal balance between pituitary gland and gonads more than injection every week. The results of Blanchard et al. (1983) were similar. In their study, the group receiving $0.55 \mathrm{mg} / \mathrm{kg}$ every week was less affected than the group receiving 1.1 $\mathrm{mg} / \mathrm{kg}$ every $3 \mathrm{rd}$ week.

In experiment I, anabolic steroid treatment of colts between 16-24 months of age reduced testic ular size during autumn and winter, but testicles started to grow during spring despite treatment with anabolic steroid. This observation is in accordance with the findings of Squires et al. (1982), who reported that the sea- 
son influenced the effect of anabolic steroids on stallions of 2-4 years of age. During the nonbreeding season, administration markedly reduced scrotal width but during summer anabolic steroid administration had little effect on total scrotal width.

We observed that difference in testicular widths in experiment I between treated and control groups diminished during the nonbreeding season. This finding is in agreement with observations by Squires et al. (1981). In their study, testicular growth during the nonbreeding season in stallions previously subjected to testosterone treatment contrasted with seasonally dependent decreases in testicular size in the control group. In our study, testicular widths of treated colts remained smaller than testicular widths in control animals. The difference, and differences observed later, were not statistically significant.

The responses of treated animals to cessation of treatment differed between experiment III and experiments I and II. In experiment III, there was hardly any testicular growth for 4-5 months after cessation of anabolic treatment. In experiments I and II, cessation of anabolic treatment was followed by testicular growth. The different responses of the treated animals probably resulted from differences between experiments: the effect of the season was different because injections were stopped at the beginning of January in experiment III and at the end of May in experiments I and II. Treatment was given in experiment III between 14 and 35 weeks of age, mostly before the onset of puberty (Naden et al. 1990).

The results reported here indicate that the effect of 19-norandrostenololylaurate on testicular size to some extent is reversible. This finding agrees with that of Squires et al. (1981). They found that the effects of treatment of adult stallions with testosterone propionate were reversible within 3 months. In our experiments on young colts and foals, a full equivalence was not reached, and recovery was slower between 4 and 12 months after cessation of injections, depending on the age of the animals at the time of treatment. It is concluded that anabolic treatment can not only inhibit testicular growth, but decrease testicular size in young colts. This effect can be reversible. The intensity of the effect of treatment depends on dose, dose interval and age of animal during treatment.

\section{References}

Berndtson WE, Hoyer JH, Squires EL, Pickett BW: Influence of exogenous testosterone on sperm production, seminal quality and libido of stallions. J. Reprod. Fertil. Suppl., 1979, 27, 19-23.

Blanchard TL, Elmore RG, Youngquist RS, Loch WE, Hardin DK, Bierschwal CJ, Ganjam VK, Balke $J M$, Ellersieck MR, Dawson LJ, Miner WS: The effects of stanozolol and boldenone undecylenate on scrotal width, testis weight, and sperm production in pony stallions. Theriogenology, 1983 , 20, 121-131.

Naden J, Amann RP, Squires EL: Testicular growth, hormone concentrations, seminal characteristics and sexual behaviour in stallions. J. Reprod. Fertil: $1990,88,167-176$.

Squires EL, Berndtson WE, Hoyer JH, Pickett BW, Wallach SJR: Restoration of reproductive capacity of stallions after suppression with exogenous testosterone. J. Anim. Sci., 1981, 53, 1351-1359.

Squires EL, Todter GE, Berndtson WE, Pickett BW: Effect of anabolic steroids on reproductive function of young stallions. J. Anim. Sci., 1982, 3, 576-582.

Thompson DL, Pickett BW, Squires EL, Amann RP: Testicular measurements and reproductive characteristics in stallions. J. Reprod. Fertil. Suppl., 1979, 27, 13-17.

Varner DD, Schumacher J, Blanchard TL, Johnson L: Diseases and management of breeding stallions. American Veterinary Publications, 5782 Thornwood Dr, Goleta, CA 93117, 1991, page 211.

Woods GL, Garcia MC, Kenney RM: Variations in testicular size of standardbred stallions. Proc. 26th Ann. Conv. Am. Ass. Equine Practitioners, 1980, 117-121. 


\section{Sammanfattning}

Inverkan av 19-norandrostenololylaurat på testiklarnas tillväxt hos hingstföl.

Långtidsinverkan av 19-norandrostenololylaurat på testiklarnas tillväxt hos hingstföl undersöktes i 3 experiment omfattande olika åldersgrupper. I det första experimentet gavs $500 \mathrm{mg}$ av denna anabola steroid till 4 hingstföl och $100 \mathrm{mg}$ till ytterligare 4 hingstföl. Behandlingarna inleddes vid 16 månaders ålder, gavs med 3 veckors interval och pågick tills fölen uppnått en ålder av 24 månader. Sex hingstföl som inte fick någon behandling var kontroller. Båda behandlingarna minskade testiklarnas totala bredd (total scrotal width, TSW) inom 6 veckor. Under behandlingsperioden var medelvärdena för TSW signifikant mindre $i$ de behandlade grupperna än i kontrollgruppen $(p=0.0198)$, men djuren som hade fått $100 \mathrm{mg}$ påverkades mindre än djuren som behandlats med $500 \mathrm{mg}$. Testiklarnas tillväxt på grund av årstidsbunden tillväxt under våren balanserade delvis ut inverkan av steroidbehandlingen i båda behandlingsgrupperna. Då behandlingen av denna anabola steroid avbröts, började testiklarna hos dessa föl växa samtidigt som TSW hos kontrollgruppen avtag. Denna effect berodde på o.a. säsongvariation. Fyra månader efter den sista injektionen var TSW hos de behandlade djuren mindre än hos kontrolldjuren, men skillnaden var inte statistiskt signifikant.

I det andra experimentet användades yngre djur med 2 olika behandlingtidsintervaller. En dos på $1 \mathrm{mg} / \mathrm{kg}$ injicerades var tredje vecka i en grupp på 4 hingstföl och $0.3 \mathrm{mg} / \mathrm{kg}$ i en grupp på 4 andra hingstföl. Sex föl fungerade som kontroller. Djuren var 7 månader gamla i början och 12 månader gamla i slutet av behandlingen. Båda behandlingarna reduserade TW (total testicular width) inom 6-9 veckor. Från tiden mellan den första mätningen av testikelstorleken till ett år efter avslutad behandling var medelvärdena signifikant olika mellan grupperna $(p=0.0182)$, men effekten hos djuren som behandlades med $0.3 \mathrm{mg} / \mathrm{kg}$ varje vecka var mindre än effekten hos djuren som behandlades med $1 \mathrm{mg} / \mathrm{kg}$ var tredje vecka. Också i detta experiment växte testiklarna då behandlingen med den anabola steroiden upphörde. Tolv månader efter den sista behandlingen var TW hos de behandlade djuren mindre än hos de obehandlade djuren, men skillnaden var inte statistiskt signifikant.

I ett tredje experiment ingick föl som var 3 månader gamla i början av experimentet och 8 månader i slutet. Tre föl behandlades med den anabola steroiden med en dos på $1 \mathrm{mg} / \mathrm{kg}$ var tredje vecka. Tre föl fungerade som kontroller. Steroidbehandlingen reduserade TW inom 6 veckor. Medelvärdena för TW i början av behandlingen och ett år efter avslutad behandling i de två grupperna skilde sig signifikant (0.0016) från varandra. Då behandlingen med den anabola steroiden avslutades, skedde långsam tillväxt av testiklarna. Tillväxten uppnådde samma hastighet som i kontrollgruppen efter ett dröjsmål på 4-5 månader efter avslutad behandling. TW i de behandlade djuren uppnådde nästan TW hos kontrollerna inom 12 månader efter att behandlingen upphört.

\section{(Received February 24, 1996; accepted November 6, 1996).}

Reprints may be obtained from: E. Koskinen, Agricultural Research Centre, Equine Research, Varsanojantie 63, FIN-32100 Ypäjä, Finland. E-mail erkki.koskinen@mtt.fi, fax: +3582 7602260. 
